\title{
EFFECTS OF PALM-BASED HIGH-OLEIC BLENDED COOKING OIL DIET ON SELECTED BIOMARKERS OF INFLAMMATION AND OBESITY COMPARED TO EXTRA VIRGIN OLIVE OIL DIET IN OVERWEIGHT MALAYSIAN ADULTS
}

\section{SIN TIEN LEE*; PHOOI TEE VOON**; TONY KOK WAI NG ${ }^{\ddagger}$; NORHAIZAN ESA*, VERNA KAR MUN LEE ${ }^{\ddagger \ddagger}$; HAZIZI ABU SAAD* and SU PENG LOH*}

\begin{abstract}
High-oleic blended cooking oil (HOBO) comprises palm olein and canola oil, with more than $50 \%$ of monounsaturated oleic acid. Studies on the effects of $\mathrm{HOBO}$ on human health is limited and therefore, this study compared the effects of $\mathrm{HOBO}$, extra virgin olive oil (OO) and coconut oil (CO) on biomarkers of inflammation, obesity and blood pressure in 32 overweight but otherwise healthy Malaysian adults. Subjects were randomised to receive three different dietary sequences, each comprising three six-week dietary periods with three-week washouts in between, utilising a double-crossover design. The HOBO, OO, and CO test fats were incorporated at $20 \% \mathrm{kcal}$ into a background diet providing $30 \% \mathrm{kcal}$ as total fat, $15 \% \mathrm{kcal}$ as protein, and $55 \% \mathrm{kcal}$ from carbohydrates. At the end of the dietary interventions, there were no significant differences ( $p>0.05)$ observed on the effects of the three test fats on all the outcome variables measured - anthropometric indices [body mass index (BMI), waist circumference (WC), waist-to-hip ratio (WHR)], serum biomarkers of obesity (serum leptin, visfatin) and inflammation [tumour necrosis factor alpha (TNF- $\alpha$ ), interleukin 6 (IL6), high-sensitivity C-reactive protein (hsCRP)].
\end{abstract}

Keywords: palm olein, high oleic, obesity, inflammation, anthropometric.

Date received: 1 May 2017; Sent for revision: 3 May 2017; Received in final form: 7 December 2017; Accepted: 2 February 2018.

\section{INTRODUCTION}

Inflammation is the body's reaction to stimulus when something that may be harmful is detected

Department of Nutrition and Dietetic,

Faculty of Medicine and Health Sciences,

Universiti Putra Malaysia, 43300 UPM Serdang,

Selangor, Malaysia.

** Malaysian Palm Oil Board,

6 Persiaran Institusi,

43000, Kajang, Selangor, Malaysia.

E-mail: vptee@mpob.gov.my

\# Department of Biomedical Sciences,

Universiti Tunku Abdul Rahman, 31900 Kampar,

Perak, Malaysia.

\# Department of Family Medicine, Institute for Research, Development \& Innovation, International Medical University, 57000 Bukit Jalil, Kuala Lumpur, Malaysia. by the immune system. Acute inflammation is the initial response to an injury or a pathogen and it may last for several days or less (Vinay et al., 2012). Chronic inflammation is next activated when the immune system mechanised by acute inflammation fails to arrest infection or heal an injury (Levine and Levine, 2012). Chronic inflammation that responds to one or more factors lasts for weeks, months or even years.

Non-communicable diseases (NCD) such as obesity, metabolic syndrome, type 2 diabetes, atherosclerosis, cancer, and rheumatoid arthritis can be due to chronic inflammation (Calder et al., 2009). Abdominal obesity is associated with chronic low-grade inflammation resulting from an adaptive response to overfeeding (Rodriguez-Hernandez et al., 2013). Macrophage cells respond to increased 
fat cell mass by stimulating secretion of the proinflammatory cytokines-TNF- $\alpha$, IL6, and IL-1 $\beta$, which then signal the liver to produce $C$-reaction protein (CRP) and initiate the inflammatory system (Hotamisliqil, 2006). Studies show that obese persons have higher circulating levels of inflammatory cytokines and CRP compared to normal weight persons (Rodriguez-Hernandez et al., 2013).

Food consumption and dietary patterns play an important role in modulating the underlying inflammatory processes associated with chronic disease. Findings from laboratory, clinical, and epidemiologic studies showed that pro-inflammatory nutrients were associated with excess calorie intake, excess carbohydrate intake, trans fatty acids, saturated fatty acids, and omega- 6 polyunsaturated fatty acids (PUFA) (Fontana and Klein, 2007; Harvey et al., 2008; Buyken et al., 2010; Chait and Kim, 2010). Antiinflammatory nutrients, on the other hand, include omega-3 PUFA, ascorbic acid, vitamin E, polyphenols, prebiotics and probiotics.

It is well-documented that the olive oilrich Mediterranean diet has anti-inflammatory properties that is mainly attributed to the phenolic compounds and high oleic-acid content of olive oil (Basu et al., 2006; Yoneyama et al., 2007; Lucas et al., 2011; Urpi-Sarda et al., 2012; Schwingshackl et al., 2015). In addition, several studies reported that olive oil consumption did not cause weight gain and therefore might be useful in weight control (Schroder et al., 2004; Mendez et al., 2006; Schröder, 2007; Razquin et al., 2009).

High-oleic blended cooking oil (HOBO), a cooking-oil produced by the blending of palm olein and canola oil, contains higher linoleic acid $(18: 2, \omega 6)$ than either palm olein or virgin olive oil (OO), and like $\mathrm{OO}$, has oleic acid as its predominant fatty acid. Therefore, the research question is whether HOBO possesses similar beneficial effects on health as that reported for OO. Due to the limited information in this area, the present study was conducted to compare the effects of $\mathrm{HOBO}$ and $\mathrm{OO}$ on biomarkers of inflammation, obesity, and blood pressure in overweight but otherwise healthy Malaysia adults, using the highly saturated $\mathrm{CO}$ as a positive control.

\section{METHODS}

\section{Study Design}

This study was conducted at the Nutrition Unit, Malaysian Palm Oil Board (MPOB), Bandar Baru Bangi, Selangor, Malaysia. Ethical approval was obtained from the Ethics Committee for Research Involving Human Subjects (JKEUPM), Universiti Putra Malaysia (UPM), Serdang, Selangor, Malaysia with reference number FPSK_Jun(13)01. This study was also registered at Clinicaltrials.gov as NCT02245113.
A single-blind, randomised double crossover study design was used. A minimum sample size of 30 was estimated based on $80 \%$ power to detect a difference between serum C-peptide means (effect size) of 228 pmol litre $^{-1}$ at a significance level of $p$ $=0.01$ (Filippou et al., 2014). A health screening, which included an array of biochemical tests, was conducted and 35 subjects with the allocation for $10 \%$ dropouts, were recruited into the study. Three subjects who failed to follow the study protocol during the intervention were withdrawn from the study. The remaining 32 subjects completed the study (Figure 1).

Prior to the test-fat interventions, all subjects underwent a three-week standardisation period on a palm olein diet which provided $30 \% \mathrm{kcal}$ from fat, $15 \% \mathrm{kcal}$ from protein, and $55 \% \mathrm{kcal}$ from carbohydrate. At the end of the standardisation period, the subjects were stratified by a computer program based on fasting total cholesterol (TC) and serum c-peptide levels, gender, and menstrual cycle (for females) and randomly allocated to three different diets prepared with test fats $\mathrm{HOBO}, \mathrm{OO}$, and coconut oil (CO). Using a Latin Square design, each group of 11-12 subjects was provided with a different dietary sequence of the three test fats; each dietary period lasted six weeks with a three-week washout in between (Figure 2).

\section{Subjects}

Informed consent was obtained from the volunteers prior to the health screening and recruitment. A questionnaire on medical history and lifestyle, as well as an array of biochemical tests (hematology, lipid profile, and liver function tests) were used to assess the health status of the volunteers. Pre-menopausal female volunteers underwent a pregnancy test using test kits from Avo Diagnostics, Malaysia. Inclusion criteria for the screened subjects were overweight [body mass index (BMI) 23.0 - $27.5 \mathrm{~kg} \mathrm{~m}^{-2}$ ] males and females; aged 20-60 years; free from diseases such as cardiovascular diseases (CVD), diabetes, cancer and liver disorder; not on any medication or treatment associated with reduction of CVD risk; female volunteers who were not pregnant or lactating. Exclusion criteria of the subjects were planning to go out-station/abroad during the period of the study, having serum TC $>7.0 \mathrm{mmol}$ litre $^{-1}$; with blood clotting problem, coagulopathy or deep-vein thrombosis; hypertensive (SYS BP > $140 \mathrm{mmHg}$, DIS $\mathrm{BP}>90 \mathrm{mmHg}$ ); alcoholics; chronic smokers.

\section{Anthropometric Measurements and Indices}

Heights, weights and BMI were recorded using a SECA height measurement meter and weighing scale, Tanita (BC-418, USA). A non-stretchable 


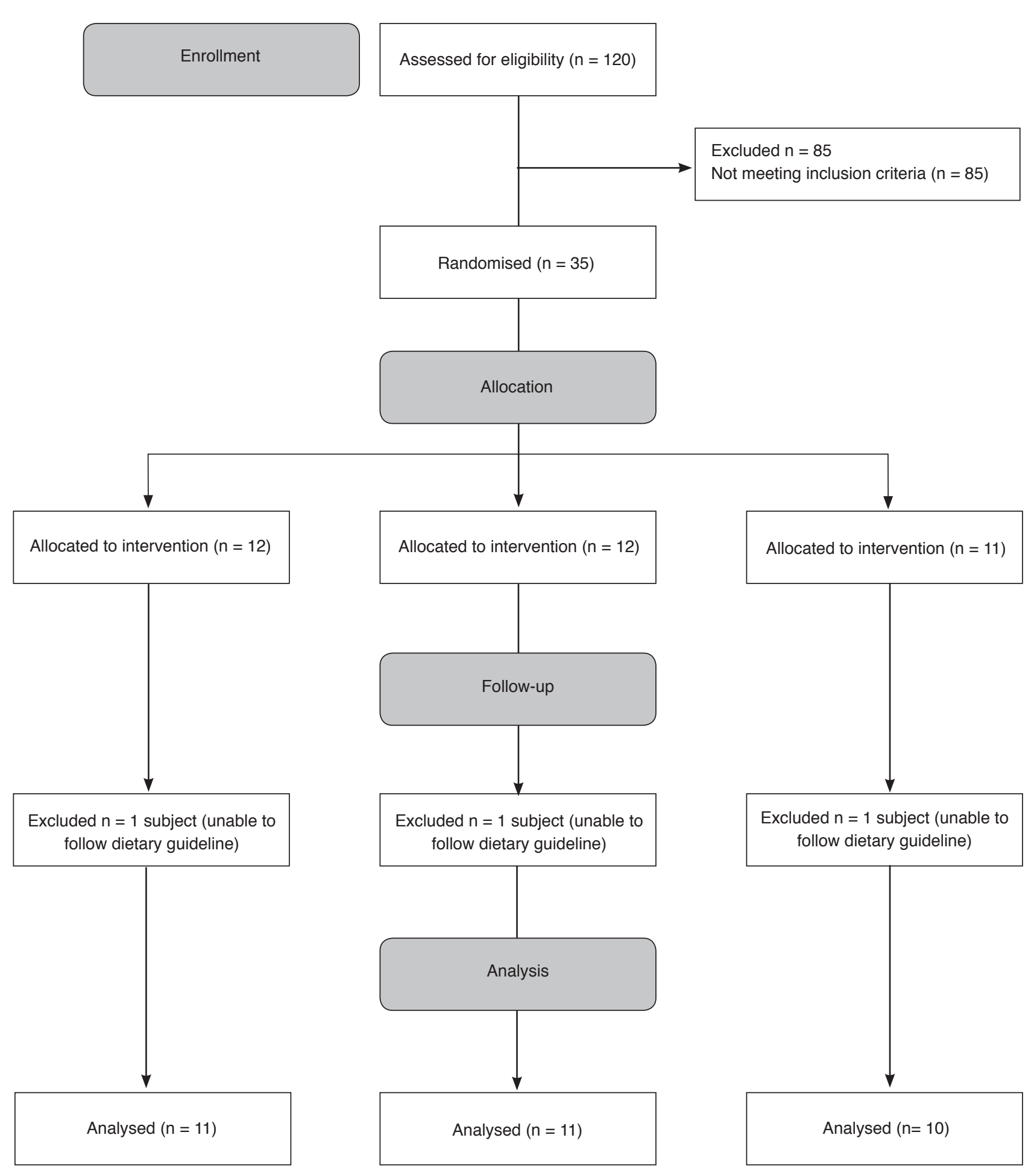

Figure 1. Consort diagram of the study.

measuring tape was used to measure waist- and hip-circumference of subjects. Waist was measured at the smallest circumference of natural waist and hip at the widest part of buttock. The waist-to-hip ratio (WHR) was obtained as waist circumference divided by hip circumference. Blood pressures of subjects were measured using OMRON 705 CPll automated upper arm blood pressure device.

\section{Test Fats and Diets}

HOBO - a palm olein-canola cooking oil blend was registered as NoveLin, a trademark technology by MPOB. HOBO was produced and supplied by Ace Edible Oil Industries Sdn Bhd (Klang, Selangor, Malaysia). OO was imported from Spain by a local distributor (Chemney Sdn Bhd, Selangor, Malaysia) 


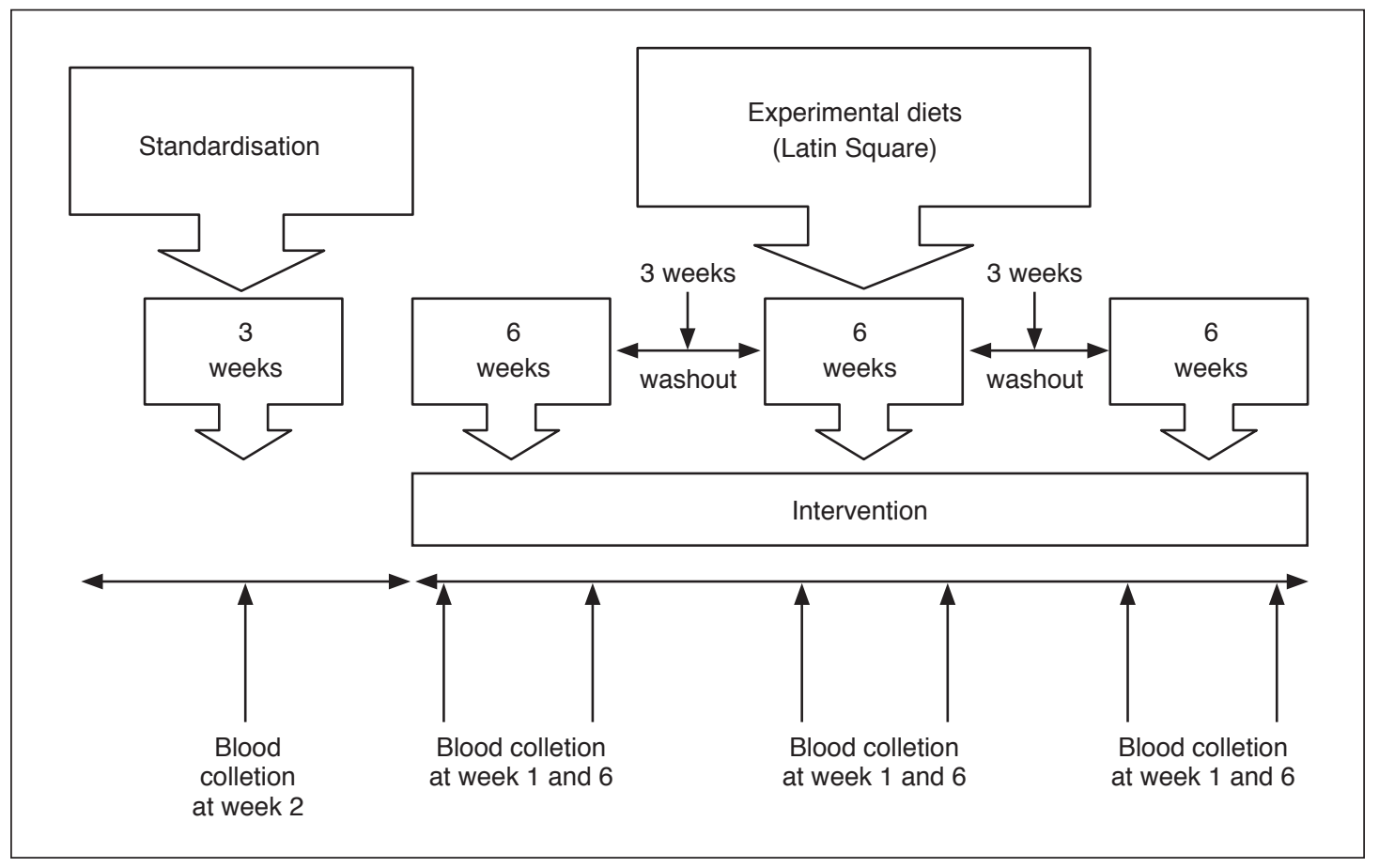

Figure 2. Flow of study.

and $\mathrm{CO}$ was purchased from PGEO Edible Oils Sdn Bhd (Pasir Gudang, Johor, Malaysia). The test diets supplied approximately $2000 \mathrm{kcal}$, with 30\% kcal total fat (two to third or $20 \% \mathrm{kcal}$ from test fat), $15 \%$ kcal protein, and 55\% kcal carbohydrate. Two sets of five-day menus were planned using NutritionistPro Software (AXXYA Systems LLC, Stafford, TX, USA) and alternately rotated for meal preparation biweekly during the six-week dietary periods.

During the standardisation and dietary interventions, subjects were provided with three daily meals (breakfast, lunch and dinner) on working weekdays. Subjects ate their breakfast and lunch at the dining hall of Nutrition Unit, MPOB. Dinner was packed into labelled containers for the subjects to collect for home consumption. Dietary guidelines were provided to subjects, which included meal preparation with the test fats at home during weekends or public holiday(s). Triplicate portions of sample test diets from different groups were collected during the study for proximate (fat, protein, carbohydrate) and fatty acid composition analysis (Perkin Elmer Autosystem Gas Chromatography).

\section{Biochemical Analysis}

As shown in Figure 2, 12-hr fasting blood samples were collected from subjects on the first day (baseline) and at the end of each six-week dietary period for the analysis of obesity biomarkers - serum leptin, visfatin, and inflammatory biomarkers serum TNF- $\alpha$, IL6, hsCRP. Freshly-collected blood samples were transferred into serum tubes (BD
Vacutainer® serum tubes, Franklin Lakes, NJ) and stood for approximately $30 \mathrm{~min}$ at room temperature before centrifugation at $1300 \mathrm{~g}$ for $15 \mathrm{~min}$ (at $4^{\circ} \mathrm{C}$ ). The upper serum layers were separated and stored at $-80^{\circ} \mathrm{C}$ freezer prior to analyses.

HsCRP concentrations were analysed by immunoturbidimetric assay using Roche/Hitachi 901 autoanalyser. Enzyme-linked immunosorbent assay (ELISA) was used to determine serum leptin (R\&D System, DY398, USA), visfatin (MyBioSource, MBS164892, USA), TNF- $\alpha$ (R\&D System, DY210, USA) and IL6 concentrations (R\&D System, DY206, USA).

\section{Statistical Analysis}

Data was analysed using repeated-measures analysis of variance (ANOVA), through the Bonferroni post hoc analysis using PASW Statistic 20 software (SPSS Inc, USA). Shapiro-Wilk's normality test was used to check the normal distribution of data. Homogeneity of variance test was run through all the data. Results were expressed as means \pm SD. Significant difference was determined at $\mathrm{p}<0.05$.

\section{RESULTS}

The dietary intake of the 32 subjects and fatty acid composition of the three test diets are shown in Table 1. The three main fatty acids contained in the HOBO diet were $11.8 \pm 3.2 \%$ kcal oleic acid, $6.0 \pm$ $1.1 \%$ kcal palmitic acid, and $4.3 \pm 1.2 \% \mathrm{kcal}$ linoleic 
TABLE 1. PROXIMATE AND FATTY ACID COMPOSITION OF THE THREE TEST DIETS

\begin{tabular}{lccc}
\hline & OO & HOBO & CO \\
\hline Energy, kcal & $2040.6 \pm 99.5$ & $1986.6 \pm 131.7$ & $2010.3 \pm 116.8$ \\
Energy, $\%$ & & \\
Protein & $13.2 \pm 1.2$ & $13.1 \pm 1.0$ & $13.3 \pm 1.0$ \\
Fat & $29.0 \pm 4.1$ & $27.9 \pm 3.9$ & $28.5 \pm 4.6$ \\
Carbohydrate & $57.8 \pm 4.1$ & $59.0 \pm 4.3$ & $58.2 \pm 4.7$ \\
Fatty acids, $\%$ & & & \\
C10:0 & $0.1 \pm 0.1$ & $0.3 \pm 0.3$ & $1.4 \pm 0.3$ \\
C12:0 & $0.3 \pm 0.3$ & $1.6 \pm 2.7$ & $11.4 \pm 2.5$ \\
C14:0 & $0.3 \pm 0.2$ & $1.2 \pm 1.1$ & $5.0 \pm 1.1$ \\
C16:0 & $4.2 \pm 0.9$ & $6.0 \pm 1.1$ & $4.0 \pm 0.9$ \\
C18:0 & $0.9 \pm 0.1$ & $0.9 \pm 0.1$ & $1.0 \pm 0.2$ \\
C18:1 & $18.3 \pm 3.0$ & $11.8 \pm 3.2$ & $3.9 \pm 2.3$ \\
C18:2 & $3.0 \pm 0.9$ & $4.3 \pm 1.2$ & $2.0 \pm 0.8$ \\
C18:3 & $0.1 \pm 0.1$ & $0.1 \pm 0.0$ & $0.0 \pm 0.0$ \\
C20:0 & $0.3 \pm 0.1$ & $0.7 \pm 0.2$ & $0.2 \pm 0.1$ \\
SFA & $6.2 \pm 0.8$ & $10.6 \pm 3.1$ & $23.0 \pm 4.6$ \\
MUFA & $18.3 \pm 3.0$ & $11.8 \pm 3.2$ & $3.9 \pm 2.3$ \\
PUFA & $3.2 \pm 0.9$ & $4.4 \pm 1.2$ & $2.0 \pm 0.8$ \\
Others & $1.3 \pm 0.3$ & $1.0 \pm 0.2$ & $0.7 \pm 10.3$ \\
\hline
\end{tabular}

Note: CO - refined, bleached and deodourised coconut oil; HOBO - high-oleic blended cooking oil; MUFA - monounsaturated fatty acid; $\mathrm{OO}$ - extra virgin olive oil; FAC - fatty acid composition; PUFA - polyunsaturated fatty acid; SFA - saturated fatty acid.

All values are means $\pm S D$.

acid. The $\mathrm{OO}$ diet contained the highest level of monounsaturated oleic acid $(18.3 \pm 3.0 \% \mathrm{kcal})$ and the lowest total saturated fatty acid (SFA, $6.2 \pm 0.8 \%$ kcal) content as mainly palmitic acid, compared to $\mathrm{HOBO}$ and $\mathrm{CO}$ diets. The positive control- $\mathrm{CO}$ diet contained the highest SFA $(23.0 \pm 4.6 \% \mathrm{kcal})$, mainly as lauric $(11.4 \pm 2.5 \% \mathrm{kcal})$ and myristic acids $(5.0 \pm$ $1.1 \% \mathrm{kcal})$.

The baseline characteristics of the 32 Malaysian subjects are shown in Table 2; mean age was $30.3 \pm$ 8.1 years, all were overweight with BMI above 23.0 $\mathrm{kg} \mathrm{m}^{-2}$ and a mean BMI of $25.5 \pm 1.7 \mathrm{~kg} \mathrm{~m}^{-2}$. The mean fasting serum IL6, TNF- $\alpha$, leptin, visfatin, and hsCRP were $7.61 \pm 26.63 \mathrm{pg} \mathrm{ml}^{-1}, 4.37 \pm 21.21 \mathrm{pg} \mathrm{ml}^{-1}$, $13.49 \pm 7.75 \mathrm{ng} \mathrm{ml}^{-1}, 0.49 \pm 1.40 \mathrm{ng} \mathrm{ml}^{-1}$, and $2.96 \pm$ $3.83 \mathrm{mg}$ litre $^{-1}$, respectively.

The anthropometric indices (BMI, WC, and WHR), blood pressures (SYS BP, DIS BP, and pulse), serum concentrations of obesity biomarkers (leptin and visfatin) and inflammatory biomarkers (TNF- $\alpha$, IL6, and hsCRP) of the 32 subjects at the end of the sixth week of each test-fat intervention are shown in Table 3. There were no significant differences ( $p>$ $0.05)$ among treatments for all outcome variables analysed. WC for women were $86.5 \pm 6.3 \mathrm{~cm}, 85.4$ $\pm 6.6 \mathrm{~cm}$, and $84.2 \pm 6.4 \mathrm{~cm}$ for $\mathrm{OO}, \mathrm{HOBO}$, and $\mathrm{CO}$ diets, respectively. For men, the same outcome variables were $88.9 \pm 4.9 \mathrm{~cm}, 89.7 \pm 5.4 \mathrm{~cm}$, and 89.2 $\pm 4.8 \mathrm{~cm}$ for $\mathrm{OO}, \mathrm{HOBO}$, and $\mathrm{CO}$ diets, respectively. WHR for women were $0.85 \pm 0.04,0.86 \pm 0.05$, and $0.85 \pm 0.05$ for $\mathrm{OO}, \mathrm{HOBO}$, and $\mathrm{CO}$ diets, respectively. For men, the WHR were $0.85 \pm 0.06,0.83 \pm 0.05,0.84$ \pm 0.04 for $\mathrm{OO}, \mathrm{HOBO}$, and $\mathrm{CO}$ diets, respectively.

\section{DISCUSSION}

In this study, 'overweight' based on the more stringent, lower cut-off of $23.0 \mathrm{~kg} \mathrm{~m}^{-2}$ recommended for Asian populations by WHO was used instead of the usual cut-off of $25.0 \mathrm{~kg} \mathrm{~m}^{-2}$ (WHO Expert Consultation, 2004). The subjects in this study had BMI of $23.0-27.5 \mathrm{~kg} \mathrm{~m}^{-2}$ and were considered to be overweight but otherwise healthy, as established

TABLE 2. BASELINE CHARACTERISTICS OF THE 32 STUDY SUBJECTS

\begin{tabular}{ll}
\hline Characteristic & Values \\
\hline N & 32 \\
Men & 13 \\
Women & 19 \\
Age $(\mathrm{y})^{*}$ & $30.3 \pm 8.1$ \\
BMI $\left(\mathrm{kg} \mathrm{m}^{-2}\right)^{*}$ & $25.5 \pm 1.7$ \\
WHR & $0.85 \pm 0.05$ \\
SYS BP $\left(\mathrm{mmHg}^{*}\right.$ & $117 \pm 10$ \\
DIS BP $\left(\mathrm{mmHg}^{*}\right.$ & $74 \pm 5$ \\
Leptin $\left(\mathrm{ng} \mathrm{ml}^{-1}\right)^{*}$ & $13.49 \pm 7.75$ \\
Visfatin $\left(\mathrm{ng} \mathrm{ml}^{-1}\right)^{*}$ & $0.49 \pm 1.40$ \\
TNF- $\alpha\left(\mathrm{pg} \mathrm{ml}^{-1}\right)^{*}$ & $4.37 \pm 21.21$ \\
IL6 $(\mathrm{pg} \mathrm{ml})^{-1}$ & $7.61 \pm 26.63$ \\
hsCRP $\left(\mathrm{mg} \mathrm{litre}^{-1}\right)^{*}$ & $2.96 \pm 3.83$ \\
\hline
\end{tabular}

Note: BMI - body mass index; BP - blood pressure;

DIS BP - diastolic blood pressure; hsCRP - high-sensitivity C-reactive protein; IL6 - interleukin 6; SYS BP - systolic blood pressure; TNF- $\alpha$ - tumour necrosis factor alpha; WHR - waist-to-hip ratio. ${ }^{*}$ Mean \pm SD (all such values). 
TABLE 3. ANTHROPOMETRIC MEASURES, BLOOD PRESSURES, AND FASTING SERUM CONCENTRATIONS OF SELECTED BIOMARKERS OF THE 32 SUBJECTS AT THE END OF OO, HOBO AND CO INTERVENTIONS

\begin{tabular}{|c|c|c|c|}
\hline Characteristic & OO & НОВО & $\mathrm{CO}$ \\
\hline \multicolumn{4}{|c|}{ Anthropometric measures } \\
\hline $\mathrm{BMI}\left(\mathrm{kg} \mathrm{m}^{-2}\right)$ & $25.52 \pm 1.64$ & $25.64 \pm 1.69$ & $25.58 \pm 1.78$ \\
\hline $\mathrm{WC}(\mathrm{cm})$ & $87.5 \pm 5.8$ & $87.1 \pm 6.4$ & $86.2 \pm 6.2$ \\
\hline WHR & $0.85 \pm 0.05$ & $0.85 \pm 0.06$ & $0.84 \pm 0.05$ \\
\hline \multicolumn{4}{|l|}{$\mathrm{BP}$} \\
\hline SYS BP (mmHg) & $117 \pm 10$ & $119 \pm 10$ & $118 \pm 11$ \\
\hline DIS BP (mmHg) & $75 \pm 8$ & $75 \pm 9$ & $74 \pm 9$ \\
\hline Pulse $\left(\min ^{-1}\right)$ & $72 \pm 10$ & $76 \pm 12$ & $75 \pm 7$ \\
\hline \multicolumn{4}{|l|}{ Fasting serum } \\
\hline Leptin $\left(\mathrm{ng} \mathrm{ml} \mathrm{l}^{-1}\right)$ & $12.41 \pm 6.69$ & $13.37 \pm 7.93$ & $12.84 \pm 8.16$ \\
\hline Visfatin (ng ml-1) & $0.48 \pm 1.42$ & $0.43 \pm 1.11$ & $0.39 \pm 0.89$ \\
\hline TNF- $\alpha\left(p g \mathrm{ml}^{-1}\right)$ & $4.08 \pm 20.52$ & $3.67 \pm 15.62$ & $1.33 \pm 6.13$ \\
\hline IL6 $($ pg ml-1) & $6.49 \pm 22.80$ & $7.55 \pm 27.90$ & $5.42 \pm 20.35$ \\
\hline hsCRP (mg litre ${ }^{-1}$ ) & $2.88 \pm 3.29$ & $2.58 \pm 3.13$ & $3.25 \pm 3.91$ \\
\hline
\end{tabular}

Note: BMI - body mass index, BP - blood pressure; CO - refined, bleached and deodourisedcoconut oil; DIS BP - diastolic blood pressure; HOBO - high-oleic blended cooking oil; hsCRP - high-sensitivity C-reactive protein; IL6 - inter leukin 6; SYS BP-systolic blood pressure; OO - extra virgin olive oil; TNF- $\alpha$, - tumour necrosis factor alpha; WC - waist circumference; WHR - waist-to-hip ratio. Different superscript letters in the same row indicate that values showed statistically significant differences $(\mathrm{P}<0.05$, Bonferroni multiple comparison test) between corresponding columns. Mean \pm SD (all such values).

by the screening tests conducted during the recruitment of subjects. The authors considered that this represented an 'innovation' over the customary use of normal-weight subjects, and that the present overweight subjects were more vulnerable to metabolic change when 'challenged' by the test fats in the study.

The linoleic acid $(18: 2, \omega-6)$ content was not standardised across the three test-fat diets because the aim of the study was to determine the effects of the commercially-available cooking oils. It was also important to keep CO in its natural state as a highlysaturated oil since it was used as a positive control in the study.

No significant difference $(p>0.05)$ was observed for all outcome variables among treatment groups - the obesity and inflammatory biomarkers, as well as the blood pressure measurements. A six-week dietary period used in the present study, which was longer than the usual three- or four-week interventions used in other studies (Choudhury et al., 1995; Tholstrup et al., 2011), was considered sufficient time to modulate any change if any, brought about by the test fats.

At the end of the dietary interventions, the subjects were maintained at overweight BMI, which were $25.64 \pm 1.69 \mathrm{~kg} \mathrm{~m}^{-2}, 25.52 \pm 1.64 \mathrm{~kg} \mathrm{~m}^{-2}$, and $25.58 \pm 1.78 \mathrm{~kg} \mathrm{~m}^{-2}$ for $\mathrm{HOBO}, \mathrm{OO}$, and $\mathrm{CO}$ diets, respectively. This means that the three test fats did not induce any significant weight change for the six weeks of dietary intervention.
Waist circumference (WC) is a useful surrogate marker for abdominal obesity and coupled with $\mathrm{BMI}$, predicts obesity-related health risk better than BMI alone (WHO, 2000; Ardern et al., 2003; Janssen et al., 2004). For Asians, the WHO had suggested WC cut-offs for increased risk as: men $>90 \mathrm{~cm}$, women $>80 \mathrm{~cm}$ (WHO, 2008). At the end of the dietary intervention, women subjects had mean WC of 84.2 $-86.5 \mathrm{~cm}$, and the men subjects $88.9-89.7 \mathrm{~cm}$. More importantly, there was no significant difference $(\mathrm{p}>$ 0.05) in WC among the three test fat groups.

The WHR also has been used to show increased risk for metabolic complications. WHO (2008) had recommended WHR cut-off of $\geq 0.90$ for men and $\geq 0.85$ for women. In this study, there were no significant differences in WHR among the three test fat diets after the dietary intervention.

According to National Heart, Lung, and Blood Institute of the National Institutes of Health, the normal blood pressure for healthy adults is defined as a SYS BP below $120 \mathrm{mmHG}$ and a DIS BP below $80 \mathrm{mmHg}$. The blood pressures of the subjects were normal even they were overweight and no significant difference found among the test fat groups after six weeks of dietary intervention. This showed that the three test diets did not affect blood pressure of overweight but otherwise healthy persons.

The inflammatory state is characterised by increased levels of pro-inflammatory cytokines - TNF- $\alpha$ and IL6 (Shoelson et al., 2003). Obesity is the leading cause of insulin resistance and type 2 
diabetes, and is associated with increased TNF- $\alpha$ levels (Tzanavari et al., 2010). Reference ranges reported for TNF- $\alpha$ and IL6 vary greatly. Sekiyama et al. (1994) reported concentration ranges for TNF- $\alpha$ of $42-203 \mathrm{pg} \mathrm{ml}^{-1}$ and IL6 of 13 - $149 \mathrm{pg} \mathrm{ml}^{-1}$ in healthy adults. Arican et al. (2005), on the other hand, reported much lower TNF- $\alpha$ values of 0.0 $32.5 \mathrm{pg} \mathrm{ml}^{-1}$ and IL6 of $0.0-12.7 \mathrm{pg} \mathrm{ml}^{-1}$ in healthy subjects. The present study obtained a wide range of TNF- $\alpha$ and IL6 concentrations for the overweight subjects but the values were within normal range as compared to reports by Sekiyama et al. (1994) and Arican et al. (2005) (Sekiyama et al., 1994; Arican et al., 2005)

CRP is commonly used to screen for inflammation or infection. For chronic inflammation, studies had shown that hsCRP was able to predict cardiovascular events (Mendall et al., 1996; Ridker et al., 1997; 1998; 2000; Roivainen et al., 2000; Rifai and Ridker, 2001). The American Heart Association and US Centre for Disease Control and Prevention had defined hsCRP risk as: low risk group with hsCRP level $<1.0 \mathrm{mg}$ litre $^{-1}$, average risk group with hsCRP 1.0 - $3.0 \mathrm{mg}$ litre $^{-1}$, and high risk group with hsCRP $>3.0 \mathrm{mg}$ litre $^{-1}$. There were no significant differences among the three test-fat diets; however, mean hsCRP value of the group on the $\mathrm{CO}$ diet was $>3.0 \mathrm{mg}$ litre $^{-1}$ which meant 'high risk'. The variation of the hsCRP values within each group was very large ranging from $0.2 \mathrm{mg} \mathrm{litre}^{-1}$ to $16.8 \mathrm{mg}$ litre $^{-1}$ and hence no significant difference could be detected among the experimental groups for this outcome variable.

The biochemical serum markers of obesityleptin and visfatin were measured in this study to detect sub-clinical changes if any, and to support any increment obtained for in BMI. Leptin is secreted mainly by adipocytes and its levels are positively correlated to the amount of body fat (Considine et al., 1996; Klok et al., 2007). Considine et al. (1996) reported serum leptin concentrations of $7.5 \pm 9.3$ $\mathrm{ng} \mathrm{ml} \mathrm{m}^{-1}$ in 136 normal-weight subjects and elevated values of $31.3 \pm 24.1 \mathrm{ng} \mathrm{ml}^{-1}$ in 139 obese subjects. Kazmi et al. (2013) had also reported that serum leptin concentrations were positively correlated with BMI, with mean leptin values of $52.8 \pm 24.6$ $\mathrm{ng} \mathrm{ml} \mathrm{m}^{-1}$ for 40 obese subjects compared with $6.3 \pm$ $3.1 \mathrm{ng} \mathrm{ml}{ }^{-1}$ for 50 non obese subjects, while leptin levels in overweight subjects were in between that of the obese and non obese groups. In the present study, the range of $12.41-12.84 \mathrm{ng} \mathrm{ml}^{-1}$ obtained for serum leptin concentrations of the 32 subjects did not reflect overweight status when compared to the much higher serum leptin concentrations reported for such individuals in previous studies.

One of the markers of obesity - visfatin was measured and the results showed that there were no significant differences in this variable among the three test-fat groups. Visfatin is a newly discovered adipocyte hormone in 2004 that it is predominantly produced and secreted in visceral fat (Fukuhara et al., 2005). However, it was subsequently demonstrated to be expressed in almost every tissue of the human body (Curat et al., 2006; Varma et al., 2007; Costford et al., 2010; Garten et al., 2010; Pavlova et al., 2015). Later, visfatin was found involved and correlated with inflammatory phenomena, atheroslcerosis and insulin secretion (Chen et al., 2006; Curat et al., 2006; Dogru et al., 2007; Varma et al., 2007; Aller et al., 2009; Liu et al., 2009). However, its physiological role is still controversial and more studies needed.

The limitations of the study include the noncontrol of physical activity of the subjects during the study. It was important that the subjects adhere to their usual physical activity pattern during the study, as any change in this aspect could confound the results. The variation in some of the biochemical indices was very large relative to their respective mean values. This could have masked any difference in treatment effect in the study.

\section{CONCLUSION}

There was no significant difference among the $\mathrm{HOBO}, \mathrm{OO}$ and $\mathrm{CO}$ experimental fats for all the outcome variables investigated in the study.

\section{ACKNOWLEDGEMENT}

The authors would like to express their appreciation to the Director-General of MPOB for the approval to publish the finding. Also, the authors would like to acknowledge the laboratory technicians and staff from the Nutrition Unit of MOPB for their assistance in conducting the study.

\section{REFERENCES}

ALLER, R; DE LUIS, D A; IZAOLA, O; SAGRADO, M G; CONDE, R; VELASCO, M C; ALVAREZ, T; PACHECO, D and GONZALEZ, J M (2009). Influence of visfatin on histopathological changes of non-alcoholic fatty liver disease. Digestive Diseases and Sciences Vol. 54(8): 1772-1777.

ARDERN, C I; KATZMARZYK, P T; JANSSEN, I and ROSS, $R$ (2003). Discrimination of health risk by combined body mass index and waist circumference. Obesity Research Vol. 11(1): 135-142.

ARICAN, O; ARAL, M; SASMAZ, S and CIRAGIL, $P$ (2005). Serum levels of TNF- $\alpha$, IFN- $\gamma$, IL-6, IL-8. Mediators of Inflammation Vol. 2005(5): 273-279.

BASU, A; DEVARAJ, S and JIALAL, I (2006). Dietary factors that promote or retard inflammation. Arterioscler Thromb Vasc Biol Vol. 26(5): 995-1001. 
BUYKEN, A E; FLOOD, V; EMPSON, M; ROCHTCHINA, E; BARCLAY, A W; BRANDMILLER, J and MITCHELL, P (2010). Carbohydrate nutrition and inflammatory disease mortality in older adults. The American J. Clinical Nutrition Vol. 92(3): 634-643.

CALDER, P C; ALBERS, R; ANTOINE, J M; BLUM, $S$; BOURDET-SICARD, R; FERNS, G A; FOLKERTS, G; FRIEDMANN, P S; FROST, G S; GUARNER, F; LOVIK, M; MACFARLANE, S; MEYER, P D; M'RABET, L; SERAFINI, M; VAN EDEN, W; VAN LOO, J; VAS DIAS, W; VIDRY, S; WINKLHOFERROOB, B M and ZHAO, J (2009). Inflammatory disease processes and interactions with nutrition. $\mathrm{Br}$ J Nutr Vol. 101(Suppl 1): S1-45.

CHAIT, A and KIM, F (2010). Saturated fatty acids and inflammation: Who pays the toll? Arterioscler Thromb Vasc Biol Vol. 30(4): 692-693.

CHEN, M P; CHUNG, F M; CHANG, D M; TSAI, J C; HUANG, H F; SHIN, S J and LEE, Y J (2006). Elevated plasma level of visfatin/pre-B cell colonyenhancing factor in patients with type 2 diabetes mellitus. The J. Clinical Endocrinology and Metabolism Vol. 91(1): 295-299.

CHOUDHURY, N; TAN, L and TRUSWELL, A $S$ (1995). Comparison of palmolein and olive oil: Effects on plasma lipids and vitamin $\mathrm{E}$ in young adults. The American J. Clinical Nutrition Vol. 61(5): 1043-1051.

CONSIDINE, R V; SINHA, M K; HEIMAN, M L; KRIAUCIUNAS, A; STEPHENS, T W; NYCE, M R; OHANNESIAN, J P; MARCO, C C; MCKEE, L $\mathrm{J}$ and BAUER, T L (1996). Serum immunoreactiveleptin concentrations in normal-weight and obese humans. N Engl J Med Vol. 334(5): 292-295.

COSTFORD, S R; BAJPEYI, S; PASARICA, M; ALBARADO, D C; THOMAS, SC; XIE, H; CHURCH, T S; JUBRIAS, S A; CONLEY, K E and SMITH, $S$ R (2010). Skeletal muscle NAMPT is induced by exercise in humans. American J. Physiology, Endocrinology and Metabolism Vol. 298(1): E117-126.

CURAT, C A; WEGNER, V; SENGENES, C; MIRANVILLE, A; TONUS, C; BUSSE, $\mathrm{R}$ and BOULOUMIE, A (2006). Macrophages in human visceral adipose tissue: increased accumulation in obesity and a source of resistin and visfatin. Diabetologia Vol. 49(4): 744-747.

DOGRU, T; SONMEZ, A; TASCI, I; BOZOGLU, E; YILMAZ, M I; GENC, H; ERDEM, G; GOK, M; BINGOL, N; KILIC, S; OZGURTAS, T and BINGOL, $S$ (2007). Plasma visfatin levels in patients with newly diagnosed and untreated type 2 diabetes mellitus and impaired glucose tolerance. Diabetes Research and Clinical Practice Vol. 76(1): 24-29.

FILIPPOU, A; TENG, K T; BERRY, $S \mathrm{E}$ and SANDERS, T A (2014). Palmitic acid in the sn-2 position of dietary triacylglycerols does not affect insulin secretion or glucose homeostasis in healthy men and women. Eur J Clin Nutr Vol. 68(9): 10361041.

FONTANA, L and KLEIN, S (2007). Aging, adiposity, and calorie restriction. JAMA Vol. 297(9): 986-994.

FUKUHARA, A; MATSUDA, M; NISHIZAWA, M; SEGAWA, K; TANAKA, M; KISHIMOTO, K; MATSUKI, Y; MURAKAMI, M; ICHISAKA, T; MURAKAMI, H; WATANABE, E; TAKAGI, T; AKIYOSHI, M; OHTSUBO, T; KIHARA, S; YAMASHITA, S; MAKISHIMA, M; FUNAHASHI, T; YAMANAKA, S; HIRAMATSU, R; MATSUZAWA, $Y$ and SHIMOMURA, I (2005). Visfatin: A protein secreted by visceral fat that mimics the effects of insulin. Science Vol. 307(5708): 426-430.

GARTEN, A; PETZOLD, S; BARNIKOL-OETTLER, A; KORNER, A; THASLER, W E; KRATZSCH, J; KIESS, W and GEBHARDT, R (2010). Nicotinamide phosphoribosyltransferase (NAMPT/PBEF/ visfatin) is constitutively released from human hepatocytes. Biochemical and Biophysical Research Communications Vol. 391(1): 376-381.

HARVEY, K A; ARNOLD, T; RASOOL, T; ANTALIS, C; MILLER, E and SIDDIQUI, R A (2008). Transfatty acids induce pro-inflammatory responses and endothelial cell dysfunction. Br J Nutr Vol. 99(4): 723-731.

HOTAMISLIQIL, G S (2006). Inflammation and metabolic disorders. Nature Vol. 444(7121): 860-867.

JANSSEN, I; KATZMARZYK, P T and ROSS, R (2004). Waist circumference and not body mass index explains obesity-related health risk. The American J. Clinical Nutrition Vol. 79(3): 379-384.

KLOK, M D; JAKOBSDOTTIR, S and DRENT, M L (2007). The role of leptin and ghrelin in the regulation of food intake and body weight in humans: A review. Obesity Reviews: An Official Journal of the International Association for the Study of Obesity, Vol. 8(1): 21-34.

LEVINE, T B and LEVINE, A B (2012). Inflammation. Metabolic Syndrome and Cardiovascular Disease. Oxford, UK, Blackwell Publishing. p. 192-202.

LIU, S W; QIAO, S B; YUAN, J S and LIU, D Q (2009). Association of plasma visfatin levels with inflammation, atherosclerosis and acute coronary 
syndromes (ACS) in humans. Clinical Endocrinology Vol. 71(2): 202-207.

LUCAS, L; RUSSELL, A and KEAST, R (2011). Molecular mechanisms of inflammation. Antiinflammatory benefits of virgin olive oil and the phenolic compound oleocanthal. Current Pharmaceutical Design Vol. 17(8): 754-768.

MENDALL, M A; PATEL, P; BALLAM, L; STRACHAN, D and NORTHFIELD, T C (1996). $C$ - reactive protein and its relation to cardiovascular risk factors: A population based cross sectional study. BMJ Vol. 312(7038): 1061-1065.

MENDEZ, M A; POPKIN, B M; JAKSZYN, P; BERENGUER, A; TORMO, M J; SANCHEZ, M J; QUIROS, J R; PERA, G; NAVARRO, C; MARTINEZ, C; LARRANAGA, N; DORRONSORO, M; CHIRLAQUE, M D; BARRICARTE, A; ARDANAZ, E; AMIANO, P; AGUDO, A and GONZALEZ, C A (2006). Adherence to a Mediterranean diet is associated with reduced 3-year incidence of obesity. The J. Nutrition Vol. 136(11): 2934-2938.

PAVLOVA, T; NOVAK, $\mathrm{J}$ and BIENERTOVAVASKU, J (2015). The role of visfatin (PBEF/ Nampt) in pregnancy complications. J. Reproductive Immunology Vol. 2015(112): 102-110.

RAZQUIN, C; MARTINEZ, J A; MARTINEZGONZALEZ, M A; MITJAVILA, M T; ESTRUCH, $\mathrm{R}$ and MARTI, A (2009). A 3 years follow-up of a Mediterranean diet rich in virgin olive oil is associated with high plasma antioxidant capacity and reduced body weight gain. Eur J Clin Nutr Vol. 63(12): 1387-1393.

RIDKER, P M; CUSHMAN, M; STAMPFER, M J; TRACY, R P and HENNEKENS, C H (1997). Inflammation, aspirin, and the risk of cardiovascular disease in apparently healthy men. $\mathrm{N}$ Engl J Med Vol. 336(14): 973-979.

RIDKER, P M; CUSHMAN, M; STAMPFER, M J; TRACY, R P and HENNEKENS, C H (1998). Plasma concentration of C-reactive protein and risk of developing peripheral vascular disease. Circulation Vol. 97(5): 425-428.

RIDKER, P M; HENNEKENS, C H; BURING, J E and RIFAI, N (2000). C-reactive protein and other markers of inflammation in the prediction of cardiovascular disease in women. $N$ Engl J Med Vol. 342(12): 836-843.

RIFAI, N and RIDKER, P M (2001). High-sensitivity $C$-reactive protein: A novel and promising marker of coronary heart disease. Clin Chem Vol. 47(3): 403-411.
RODRIGUEZ-HERNANDEZ, $\mathrm{H} ; \quad$ SIMENTALMENDIA, L E; RODRIGUEZ-RAMIREZ, G and REYES-ROMERO, M A (2013). Obesity and inflammation: Epidemiology, risk factors, and markers of inflammation. Int J Endocrinol, Vol. 2013(2013): 678159.

ROIVAINEN, M; VIIK-KAJANDER, M; PALOSUO, T; TOIVANEN, P; LEINONEN, M; SAIKKU, $\mathrm{P}$; TENKANEN, L; MANNINEN, V; HOVI, T and MANTTARI, M (2000). Infections, inflammation, and the risk of coronary heart disease. Circulation Vol. 101(3): 252-257.

SCHRÖDER, H (2007). Protective mechanisms of the Mediterranean diet in obesity and type 2 diabetes. J Nutr Biochem Vol. 18(3): 149-160.

SCHRODER, H; MARRUGAT, J; VILA, J; COVAS, M I and ELOSUA, R (2004). Adherence to the traditional Mediterranean diet is inversely associated with body mass index and obesity in a spanish population. The J. Nutrition Vol. 134(12): 3355-3361.

SCHWINGSHACKL, L; CHRISTOPH, $\mathrm{M}$ and HOFFMANN, G (2015). Effects of olive oil on markers of inflammation and endothelial function - A systematic review and meta-analysis. Nutrients Vol. 7(9): 7651-7675.

SEKIYAMA, K D; YOSHIBA, M and THOMSON, A W (1994). Circulating proinflammatory cytokines (IL-1 beta, TNF-alpha, and IL-6) and IL-1 receptor antagonist (IL-1Ra) in fulminant hepatic failure and acute hepatitis. Clinical and Experimental Immunology Vol. 98(1): 71-77.

SHOELSON, S E; LEE, J and YUAN, M (2003). Inflammation and the IKK beta/I kappa B/NFkappa B axis in obesity- and diet-induced insulin resistance. Int J Obes Relat Metab Disord Vol. 27 Supp 3: S49-552.

THOLSTRUP, T; HJERPSTED, J and RAFF, M (2011). Palm olein increases plasma cholesterol moderately compared with olive oil in healthy individuals. The American J. Clinical Nutrition Vol. 94(6): 1426-1432.

TZANAVARI, T; GIANNOGONAS, P and KARALIS, K P (2010). TNF-alpha and obesity. Current Directions in Autoimmunity Vol. 11: 145-156.

URPI-SARDA, M; CASAS, R; CHIVA-BLANCH, G; ROMERO-MAMANI, ES; VALDERAS-MARTINEZ, P; ARRANZ, S; ANDRES-LACUEVA, C; LLORACH, R;MEDINA-REMON, A; LAMUELA-RAVENTOS, R M and ESTRUCH, R (2012). Virgin olive oil and nuts as key foods of the Mediterranean diet effects on inflammatory biomakers related to atherosclerosis. Pharmacological Research Vol. 65(6): 577-583. 
VARMA, V; YAO-BORENGASSER, A; RASOULI, $\mathrm{N}$; BODLES, A M; PHANAVANH, B; LEE, M J; STARKS, T; KERN, L M; SPENCER, H J, 3RD; MCGEHEE, R E, Jr; FRIED, S K and KERN, P A (2007). Human visfatin expression: Relationship to insulin sensitivity, intramyocellular lipids, and inflammation. The J. Clinical Endocrinology and Metabolism Vol. 92(2): 666-672.

VINAY, K; ABUL, K A and JON, C A (2012). Robbins basic pathology. Inflammation and Repair. Philadelphia, PA, Elsevier Health Sciences. p. 928.

WHO (2000). Obesity: preventing and managing the global epidemic. WHO Technical Report Series 894. Geneva: World Health Organization. p. 252.
WHO (2008). Waist Circumference and Waist-hip Ratio: Report of a WHO Expert Consultation. Geneva, 8-11 December 2008. Technical report, World Health Organization. p. 1-39.

WHO EXPERT CONSULTATION (2004). Appropriate body-mass index for Asian populations and its implications for policy and intervention strategies. Lancet Vol. 363(9403): 157-163.

YONEYAMA, S; MIURA, K; SASAKI, S; YOSHITA, K; MORIKAWA, Y; ISHIZAKI, M; KIDO, T; NARUSE, Y and NAKAGAWA, H (2007). Dietary intake of fatty acids and serum C-reactive protein in Japanese. J. Epidemiology /Japan Epidemiological Association Vol. 17(3): 86-92. 